\section{What's Wrong with Hungarian University Management?}

\section{Karoly Barakonyi}

Karoly Barakonyi is professor of strategic management in the Faculty of Business and Economics, Pécs University, Hungary, and former rector of the university. He was visiting Fulbright professor at the Wharton School, University of Pennsylvania. E-mail: <barakonyi@ktk.pte.hu>.

$\mathrm{H}$ ungarian university management seems to be less and less able to cope with challenges arising from such changes as mass education, student mobility, institutional integration, decreasing state support, and lifelong learning. Modernization requires new managerial knowledge, experience, and commitment. Modernization of management is a vital requirement.

The orchestra analogy may shed some light on the problem of modernizing Hungarian university management. The conductor is a determinant figure-one who defines the orchestra. The conductor's task is different from that of the musicians, and he or she needs to have a different kind of knowledge. Likewise, it is no drawback if the prospective rector, the university's conductor, has an academic title, but it is more important that he or she possess the managerial skills and knowledge required by the new challenges.

\section{Election of the Rector}

The current Hungarian procedure for electing rectors is flawed. From the medieval period until World War II the system more or less worked, as universities were relatively small and less complex structurally (higher education being an elite rather than a mass phenomenon). The rector's mandate was for one year, after which he or she returned to academic work. The appointment was an honor, with the rector as primus inter pares. Managing a contemporary university cannot simply be designed as an academic honor: it is a professional occupation. Large state universities in developed countries have long since broken with this medieval tradition. The president is usually not elected by associates, but rather appointed by a superior authority (a board or managing body). The president's mandate is not just for one year, but sometimes for a period of a decade or more (like the conductor of an orchestra).

The university community is enormously conservative: a rector can only be elected if numerous compromises are reached. A rector who wishes to launch reforms that would interfere with the interests of others is simply not elected; reforms made during the term of office might jeopardize the rector's chances of reelection. The present four-year appointment in Hungary does not allow enough time to complete a partial structural reform, never mind comprehensive modernization. The consequences of the university's conservatism include stoppage of reforms, turning back the clock, survival of old-fashioned structures, and the proliferation of pseudoreforms.

\section{Structure}

A knowledge-based organization requires a flat structurecoordination instead of the issuing of top-down instructions. A hierarchy is not an effective organizational structure. The management system of Hungarian universities is based on Humboldtian principles and follows a multistaged hierarchy (rector-faculty-institute-departmentdepartmental team-professors). Faculties are strongholds; their bastions are the departments. The consequence of this structure is the existence of numerous departments, with few academics and staff. Modern universities are changing this pattern: the many small departments are being replaced by fewer, bigger departments.

As rectors come and go, continuity should be sustained by the financial director and by the secretary general, but in Hungary they usually leave with the rector. Rectors are often unwilling to give up financial and instructional control, so these positions are filled by mediocre specialists, whose tasks are of secondary importance.

The rector's work is assisted by part-time vice rectors, who also lack managerial experience. They find themselves forced to carry out tasks that require professional preparedness. Ultimately, they, too, leave with the rector.

\section{Strategic Thinking}

The formation and successful operation of knowledgebased organizations require strategic thinking and strategic planning. The mission statement and strategic plans are the music score from which the orchestra plays. A system like that must have a well-developed internal communication system, an effective information system, a strong corporate culture, and institutional identity (especially in the case of the new integrated universities). A strategic approach and the conscious formation of institutional identity are still missing at Hungarian universities.

At a modern university the handling of educational issues and scientific matters (by the Senate) is separated from the handling of strategic and financial issues (by the board). In this way, society can have control over the use of state funding for universities. Hungarian universities require structural changes to achieve this balance.

In the contemporary Hungarian university, the position of rector may be compared to that of a national prime minister who does not have a party's support in parliament. Decisions of great significance can only be made with the consent of parties of differing interests.

The role of students should also to be questioned, since students often appear easily influenced. Their participation in strategic decision making in Hungary is exceptionally high (25 to 33 percent). Several progressive initiatives failed in many institutions because internal conservative 
powers managed to persuade uncertain student voters to take a stand on their side.

\section{Conclusion}

Progressing toward a professional university management system involves some dangers: weakened autonomy and academic freedom and excessive influence from government and business. I believe, given the present changing conditions, Hungarian higher education will only be able to fulfill social needs, improve the effectiveness of its operations, and meet new demands through the process of modernizing university management.

\section{A Review of Higher Education Reform in Bulgaria Nikolay Popov}

Nikolay Popov is associate professor of comparative education at Sofia University, Sofia, Bulgaria. E-mail: <npopov@fnpp.uni-sofia.bg>.

$\mathrm{O}$ ver the last decade higher education has been one of the most rapidly developing sectors in Bulgaria. Reforms initiated in the economic, agricultural, and social fields have faced great difficulties. Changes introduced at other levels of the educational system-preschool and primary and secondary education-have been minimal as well. In contrast, Bulgarian society has resolved that, in a time of economic and social crisis, higher education is one of the most reliable financial and intellectual investments.

\section{Reform Phases}

Even though 11 years is a relatively short span of time, higher education reform in Bulgaria has undergone several phases. Two acts affecting Bulgarian higher education were adopted in the 1990s: the Higher Education Act, passed in December 1995, and the Amendment to the Higher Education Act, passed in June 1999. The period from the initiation of political, economic, and social change in 1989 to the adoption of the 1995 Higher Education Act demarcates the first phase. From 1989 to 1990, ideological subjects and course content were abolished; study programs, curricula, and syllabi were reconceptualized (the "first wave" of curriculum reform); and communist/socialist higher education policy was subjected to widespread criticism. The following two years saw the closing of many research institutes, increasing unemployment among researchers and their transfer to other fields of activity, and the influx of new academic staff into the higher education system. New faculties and specialties were created, public universities were expanded and permitted to introduce tuition fees, and private universities and colleges were established. The system stabilized from 1993 to 1995, with the gradually ebbing of political pressure. Numerous institutes were transformed into universities, assisted by an influx of foreign assistance programs.

The second phase covers the period from the adoption of the 1995 Higher Education Act to its amendment in 1999. The act aimed to legalize the previous efforts made by Bulgarian postsecondary schools. A new system of academic degrees was introduced, and an agency for quality assessment and accreditation of postsecondary school activities was created. Efforts were made to harmonize the educational process with that of Western Europe, which involved major restrictions on educational institution finances and the development and adoption of new curricula, especially in the social sciences.

In mid-1999, the system of higher education entered a new phase, characterized by the abolition of free education and the introduction of tuition at all public universities, increased competition in admissions, and efforts to bring standards into line with the European context.

\section{Current Goals}

The goal of higher education in Bulgaria has been described as "the training of highly qualified specialists and the promotion of scientific and cultural progress." The practical aspects of this effort are (1) to provide fair and equal opportunities to all who are able and willing to pursue higher education; (2) to create admissions systems and a learning environment in postsecondary schools, corresponding to contemporary requirements; (3) to maintain and raise the quality of higher education through the establishment of criteria that will improve access for all individuals and groups of society and promote excellence in teaching and research; (4) to ensure that graduates from postsecondary schools are able to apply scientific knowledge in various spheres of human activity; and (5) to upgrade the qualifications of specialists.

\section{Current Problems}

Numerous problems with the system of higher education in Bulgaria have been identified. First, universities have much greater prestige than do colleges. A university's reputation is the result of higher standards in the quality of education offered, competitive admissions requirements, and employment prospects after graduation. Furthermore, although there are various forms of interaction between universities and colleges, the functional "bridges" between them are not well constructed. The structure of the university system ensures strict vertical and horizontal inflexibility. Vertical inflexibility is prevalent in application and 